Vol. 9 (2000): 269-278.

\title{
Three mechanical weed control techniques in spring cereals
}

\author{
Timo Lötjönen and Hannu Mikkola \\ Agricultural Research Centre of Finland, Agricultural Engineering Research, Vakolantie 55, FIN-03400 Vihti, \\ Finland, e-mail: timo.lotjonen@mtt.fi
}

\begin{abstract}
An inter-row hoe suitable for cereals was developed for the study, and field experiments were conducted to compare inter-row hoeing with weed harrowing, rotary hoeing and chemical control. The treatments were performed once during the growing season. Inter-row hoeing was studied at row spacings of $180 \mathrm{~mm}$ and $250 \mathrm{~mm}$.

The weeding effect of the different methods was measured by weighing the weeds remaining just before harvesting. Inter-row hoeing was the most effective of the mechanical methods. Weed harrowing was as good as hoeing in silty clay soil but less effective in mull soil. Rotary hoeing was the least effective. Herbicide spraying was more effective than the mechanical methods in both soils.

Increasing the spacing between rows from the standard $125 \mathrm{~mm}$ to $250 \mathrm{~mm}$ decreased the yield of barley by $12-13 \%$. Inter-row hoeing affected the yield very slightly. The yield decreasing was lower at a row spacing of $180 \mathrm{~mm}$ than at $250 \mathrm{~mm}$. Weed harrowing and rotary hoeing decreased the yield $5-10 \%$. Although inter-row hoeing seems to be a fairly effective method for weed control, it may be difficult to compensate for the yield loss due to the increase in row spacing.
\end{abstract}

Key words: inter-row hoe, rotary hoe, row spacing, spring tine harrow

\section{Introduction}

Weed control is one of the most difficult problems to be solved in organic agriculture, since herbicides cannot be used. In planning the crop rotation and all operations related to cropping, every effort must be made to prevent weeds from spreading. Even so, mechanical weed control may still be needed for control the weeds (Matts- son and Sandström 1994, Rasmussen and Ascard 1995).

Weed harrows with long spring tines are widely used by organic farmers to control weeds in cereals. The harrow partly covers the weeds with soil and partly damages them (Mattsson and Sandström 1994). Correct timing is very important in harrowing. For maximum effect, fields should be weeded when the weeds are at the seed leaf stage. At later stages harrowing is only ef- 


\section{Lötjönen, T. \& Mikkola, H. Mechanical weed control techniques}

fective if the soil covering effect is made more aggressive (Rasmussen and Svenningsen 1995, Rydberg 1995). An important advantage of weed harrowing is that the whole field cover is treated, i.e. both the area between and within the rows.

Rotary hoeing has been used in row-crops for a long time, particularly in the USA, but few experiments have been conducted in cereals (Mohler and Frisch 1997). A rotary hoe suitable for cereals partly covers the weeds with soil and partly damages them, like the spring tine harrow. Thus early weeding is most effective. The cereal rows and the surface between the rows are treated.

Inter-row hoeing has been used for decades to control weeds in row-crops (e.g. sugar beet, maize). Hoeing is also now being used in cereals. Hoeing can control larger weeds than weed harrowing and the risk of crop damage is lower (Mattsson and Sandström 1994, Johansson 1998). Because hoeing is less sensitive to weed size, the treatment period is longer than with weed harrowing. This means, that hoeing is not so dependent on the weather. Hoeing also has some effect on perennial weeds. A disadvantage is poor weed control within crop rows (Johansson 1998).

Much research has been done on mechanical weed control in cereals, e.g. in Denmark and Sweden (Rasmussen 1989, Rydberg 1995, Johansson 1998). The aims of this study were to develop a simple inter-row hoe suitable for cereals and to compare this with harrowing, rotary hoeing and chemical control.

\section{Material and methods}

The inter-row hoe was developed and preliminary experiments were conducted in 1995-1996 (Lötjönen and Mikkola 1997). In field experiments conducted in 1997-1998, the inter-row hoe was compared with the spring tine weed harrow, rotary hoe and chemical control. Also,

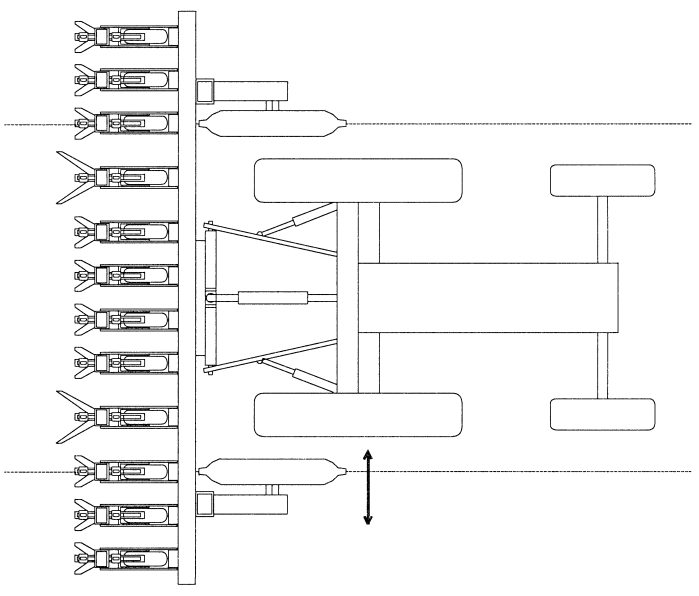

Fig. 1. The type of inter-row hoe and the steering method used in the study. Steering is marked by an arrow.

some improvements were made to the inter-row hoe during that period.

\section{Developed inter-row hoeing system}

As there was no commercially available interrow hoe designed specifically for cereals, a $3 \mathrm{~m}$ wide sugar beet hoe was modified for the tests. In order to avoid clogging problems and also to make the use of a simple and cheap steering system possible row spacings of $180 \mathrm{~mm}$ and 250 $\mathrm{mm}$ were used in the field experiments instead of the normal $125 \mathrm{~mm}$ row spacing. The spacing of $250 \mathrm{~mm}$ was selected because this could be achieved by using half of the drill coulters; for $180 \mathrm{~mm}$ the coulter position on the drill had to be modified. At the tractor wheels the spacing was $375 \mathrm{~mm}$ to avoid wheeling of the crop while hoeing.

A special steering method was used on the hoe to avoid crop damage. During drilling, two grooves are cut into the ground. The specially designed wheels of the hoe follow these grooves and steer the hoe independently of the tractor (Fig. 1). This steering method has been used for a long time to steer hoes in sugar beet. The method is simple and cheap, and works well on flat 


\section{AGRICULTURAL AND FOOD SCIENCE IN FINLAND}

Vol. 9 (2000): 269-278.

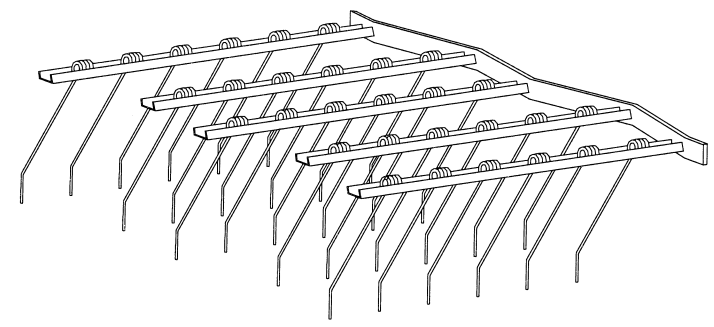

Fig. 2. The principle of the spring tine harrow.

fields. Hydraulic compensation was added to steer the hoe on slopes.

Each hoe unit has its own depth-regulating wheel. The target hoeing depth for the experiments was $20-30 \mathrm{~mm}$. The hoe was fitted with ducksfoot blades, and a 70-80 mm wide unhoed strip was left around the crop row. The blades uproot and bury small weeds and cut off the roots of larger weeds growing within their working width. They also throw soil onto the crop covering the small weeds growing in the row. The higher the driving speed, the more soil is thrown onto the row. After preliminary tests a hoeing speed of $6-8 \mathrm{~km} / \mathrm{h}$ was selected for the field experiments.

\section{Spring tine harrow}

The Hatzenbichler ${ }^{\circledR}$ spring tine harrow has flexible tines $25 \mathrm{~mm}$ apart (Fig. 2). The weed covering effect is adjusted by changing the driving speed, tine angle and/or working depth. The driving direction can be chosen freely in relation to sowing rows. Here, the harrow was driven at 6 $\mathrm{km} / \mathrm{h}$ in 1997 and at $11 \mathrm{~km} / \mathrm{h}$ in 1998 . The harrowing depth was $20-30 \mathrm{~mm}$, and the driving direction was along the sowing rows. A previous study had shown that it makes little difference whether the harrow is driven along or across the crop rows (Rydberg 1995).

\section{Rotary hoe}

The effect of a rotary hoe is created by covering

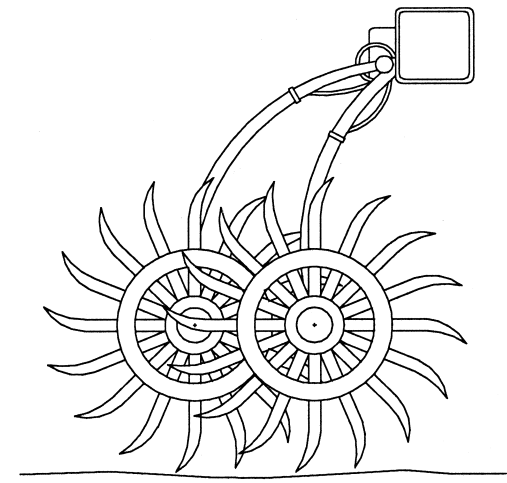

Fig. 3. The principle of the rotary hoe.

the weeds with soil and uprooting them. There are two types of rotary hoe, one that works only in the inter-row spaces and one that treats the whole field (Mohler and Frisch 1997, Pullen and Cowell 1997). The latter is suitable for cereals and it was used in our experiments.

The experiments were done with a Yetter ${ }^{\circledR}$ rotary hoe (Fig. 3). This type of hoe permits adjustments only to driving speed and direction. According to the results of the preliminary tests a speed of $13 \mathrm{~km} / \mathrm{h}$ was used and the driving direction was along the sowing rows.

\section{Field experiments in 1997-1998}

The field experiments were set up in Vihti, southern Finland. The spring barley cultivar Artturi was sown in silty clay soil and mull soil (a mixture of peat and clay) at row spacings of $125 \mathrm{~mm}$, $180 \mathrm{~mm}$ and $250 \mathrm{~mm}$ (Table 1). All plots were sown at the same seed rate, irrespective of row spacing (500 germinating seeds $/ \mathrm{m}^{2}$ ). Nutrients were applied as chemical fertilizers (NPK, N 90 $\mathrm{kg} / \mathrm{ha}$ in silty clay soil and $\mathrm{N} 60 \mathrm{~kg} / \mathrm{ha}$ in mull soil).

There were two experimental years, 1997 and 1998. The experimental design was a randomized complete block, with year and replication as blocking variables. The treatments are shown in Table 1. There were four replicates and seven treatments on both soils in both years (plot size 


\section{Lötjönen, T. \& Mikkola, H. Mechanical weed control techniques}

Table 1. Row spacings and weed treatments in 1997-1998.

\begin{tabular}{cl}
\hline Row spacings, cm & Weed control \\
\hline 12.5 & Non-weeded \\
12.5 & Chemical control \\
12.5 & Spring tine harrow \\
12.5 & Rotary hoe \\
18 & Row hoe \\
25 & Non-weeded \\
25 & Row hoe \\
\hline
\end{tabular}

$3 \mathrm{~m} \times 25 \mathrm{~m}$ ). The experimental design was identical in 1997 and 1998, but the experiments were not located at the same sites in both years.

Weed harrowing and rotary hoeing treatments were performed when the barley crop had reached a height of $50-150 \mathrm{~mm}$ and the weeds a maximum of $50 \mathrm{~mm}$. Inter-row hoeing was carried out 1-2 weeks later, when the crop was 150$250 \mathrm{~mm}$ high and the maximum weed height was $100 \mathrm{~mm}$. The Logran ${ }^{\circledR}$ low-dose herbicide (triasulfuron) was applied to the control plots at a rate of $20 \mathrm{~g} / \mathrm{ha}$, when the height of the crop was 150-200 mm. All treatments except rotary hoeing were conducted only once during the growing season. Two immediate and successive passes of the rotary hoe had to be conducted before the desired working depth was obtained.

The air temperature was slightly above the 1975-1995 average in 1997 and slightly below it in 1998 (Table 2). In 1997, the growing period started late and May was cold. Average rainfall fell in 1997, but in 1998 it was almost twice the average for May-August.

The effects of the treatments were measured by removing the remaining weeds with their roots and weighing the dry mass of the weeds. The weeds were picked symmetrically from $2 \mathrm{x}$ $(0.71 \mathrm{~m} \times 0.71 \mathrm{~m})$ areas/plot just before harvesting. The barley was harvested at the end of August and the yields were weighed. In 1998 it was so wet (Table 2) that one replication failed in mull soil. In the same year, a couple of perennial-weed patches were found in the weed sampling areas in silty clay soil. These would have so big influence on the outcome of the experi-
Table 2. Monthly growing degree-days (GDD; base temperature $5^{\circ} \mathrm{C}$ ) and rainfall at Vihti compared with averages for 1975-1995. Counting starts at the beginning of the growing period. (Source: Finnish Meteorological Institute 1999).

\begin{tabular}{lcrr}
\hline GDD, ${ }^{\circ} \mathrm{C}$ & Average $1975-95$ & 1997 & 1998 \\
\hline May & 157 & 85 & 164 \\
June & 272 & 318 & 266 \\
July & 358 & 374 & 320 \\
August & 285 & 378 & 247 \\
\hline Total & 1072 & 1154 & 997 \\
\hline Rainfall, mm & Average $1975-95$ & 1997 & 1998 \\
\hline May & 30 & 22 & 58 \\
June & 46 & 62 & 115 \\
July & 63 & 81 & 105 \\
August & 86 & 94 & 121 \\
\hline Total & 226 & 259 & 398
\end{tabular}

ment that they were omitted from the final results.

The results are given as averages for 19971998 but separately for the two soil types. The amounts of weeds and yields were higher in 1997 compared to 1998 , but differences between the treatments were nearly parallel. Interactions between the treatments were checked out with the PROC MIXED of SAS ${ }^{\circledR}$ package (SAS Institute 1988). Only barley yield results in silty clay soil seemed to have moderate interaction between the years. Because the yields were not the most important matter in this study, data from 1997 and 1998 experiments were combined. The model for this trial is:

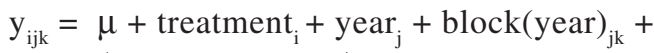

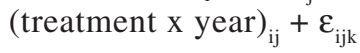

$\mathrm{y}_{\mathrm{ijk}}$ is the observation

$\mu$ is the overall mean

treatment $_{i}$ is the treatment effect

year $_{j}$ is the year effect

block(year) ${ }_{j k}$ is the random effect of the block within year

(treatment $x$ year $)_{\mathrm{ij}}$ is the treatment-by-year interaction effect

$\varepsilon_{\mathrm{ijk}}$ is the error 
Vol. 9 (2000): 269-278.

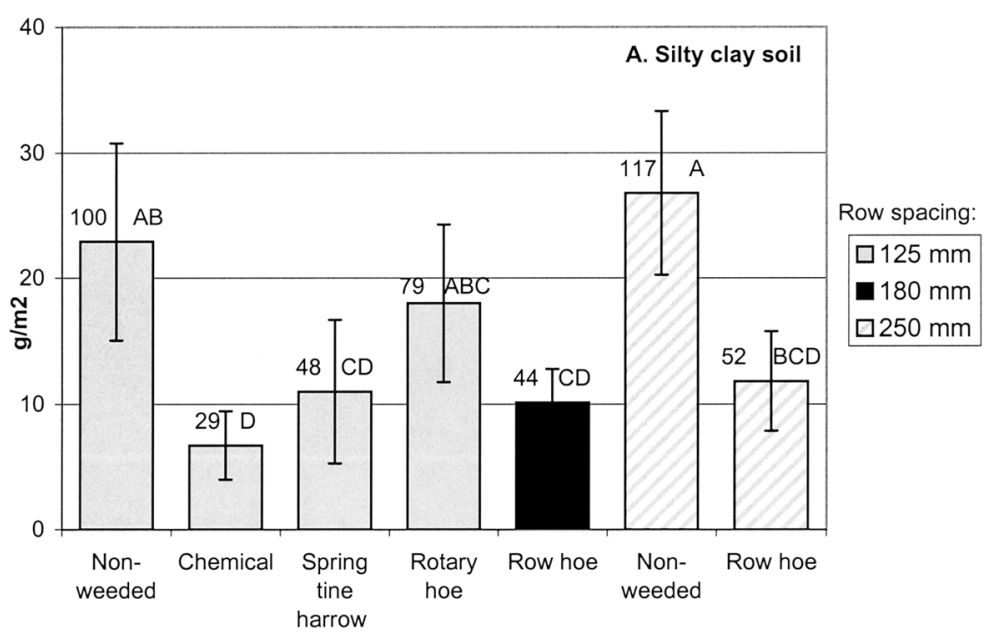

Fig. 4. Average weed dry matter $\left(\mathrm{g} / \mathrm{m}^{2}\right)$ and standard deviations before harvest in silty clay soil (A) and in mull soil (B). Data pooled over 1997-1998. The treatment "Non-weeded $125 \mathrm{~mm}$ " has been given the ratio 100 . The treatments with different letters are significantly $(\mathrm{P}<0.05)$ different.

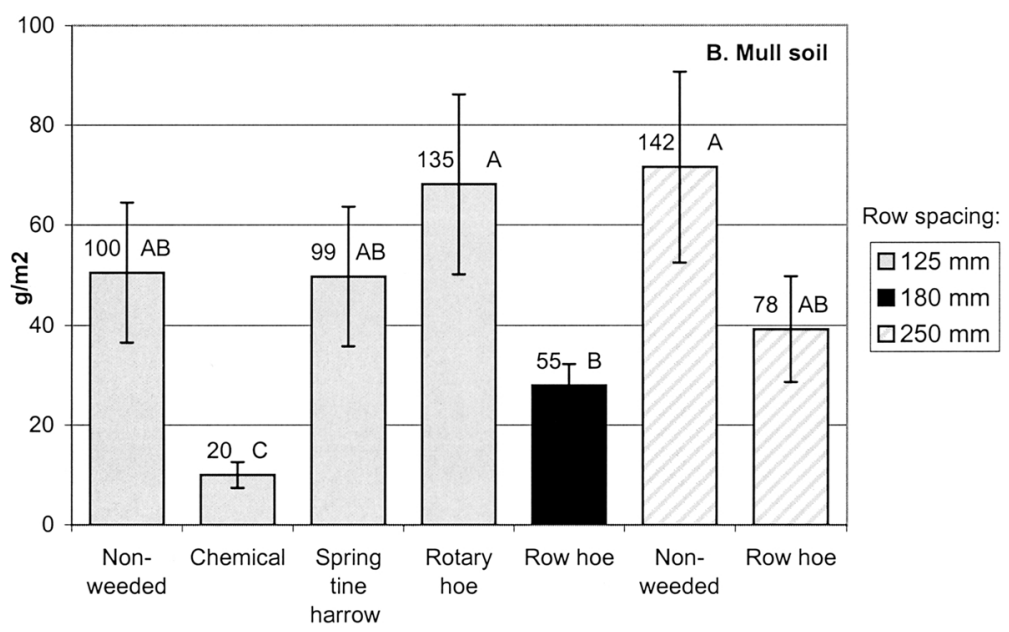

The results were submitted to analysis of variance with the PROC MIXED of SAS ${ }^{\circledR}$ package (SAS Institute 1988). Tukey's test (HSD) was used in pairwise comparisons $(\mathrm{P}=0.05)$. The data on weed dry matter was $\log (\mathrm{x})$-transformed to achieve homogeneity of variances and normal distributions. The barley-yield data was analysed without transformations.

\section{Results}

\section{Effects on weeds}

In the experiments, weed densities were lower than normal for cereal fields in Finland (173 weeds $/ \mathrm{m}^{2}$ ) (Erviö and Salonen 1987). The average weed density in silty clay soil, just before the treatments, was 130 weeds $/ \mathrm{m}^{2}$ in 1997 and 
Lötjönen, T. \& Mikkola, H. Mechanical weed control techniques
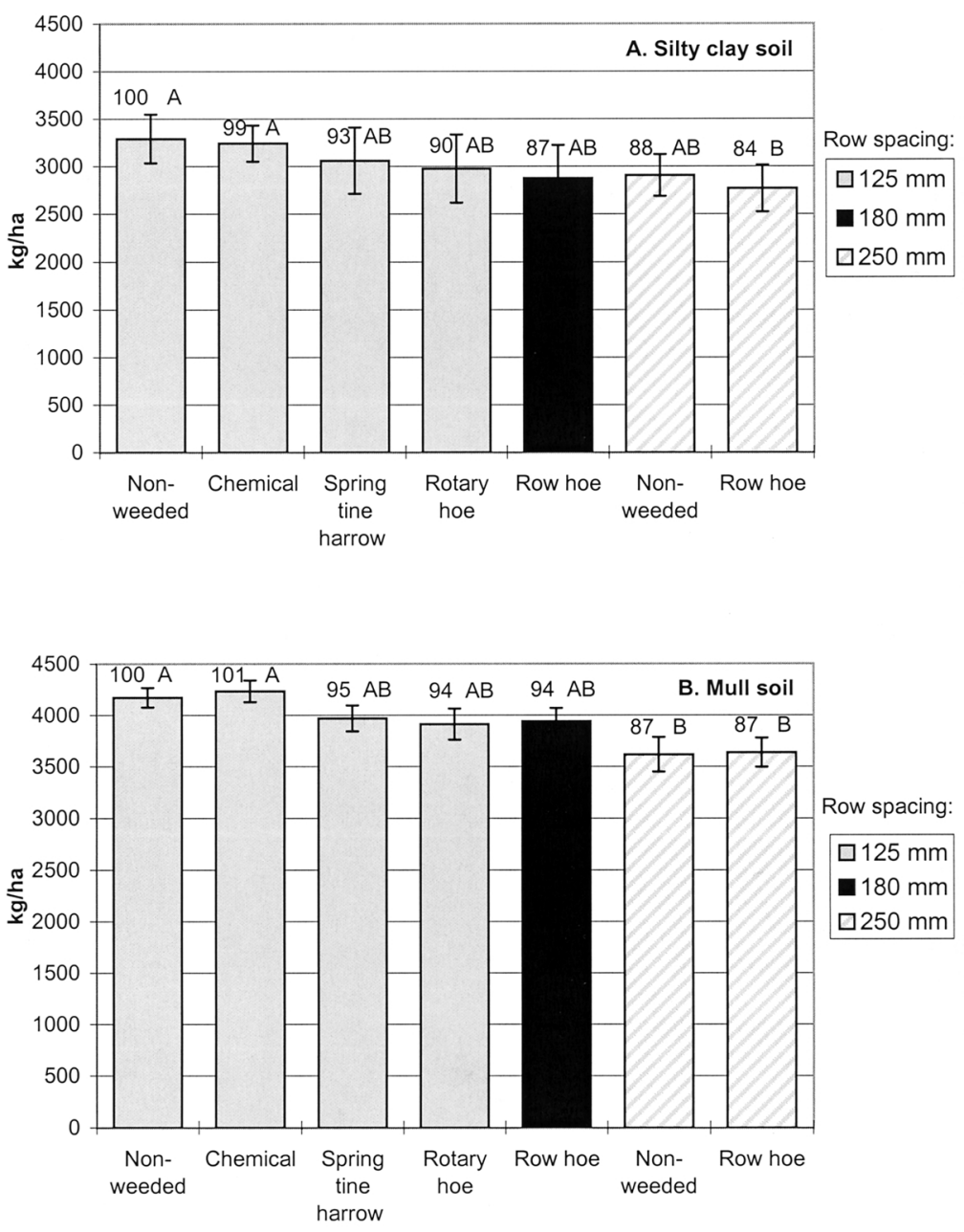

Fig. 5. Average barley yields (given in $14 \%$ water content) and standard deviations in silty clay soil (A) and in mull soil (B). Data pooled over 1997-1998. The treatment "Non-weeded $125 \mathrm{~mm}$ " has been given the ratio 100 . The treatments with different letters are significantly $(\mathrm{P}<0.05)$ different.

50 weeds $/ \mathrm{m}^{2}$ in 1998 , and in mull soil 85 weeds/ $\mathrm{m}^{2}$ and 55 weeds $/ \mathrm{m}^{2}$, respectively. The most common weed species were Galeopsis speciosa, Chenopodium album and Fumaria officinalis.

In silty clay soil before harvesting, the weed dry mass $\left(\mathrm{g} / \mathrm{m}^{2}\right)$ remaining after inter-row hoeing was $44-52 \%$ of that in non-weeded plots (row spacing $125 \mathrm{~mm}$ ) (Fig. 4). Spring tine harrowing had an equivalent effect on weeds. Correspondingly chemical spraying left on average $29 \%$ of the dry matter of the weeds.

All these treatments, except row hoeing at $250 \mathrm{~mm}$ row spacing, reduced weed dry mass statistically significantly $(\mathrm{P}<0.05)$ in comparison to non-weeded control. The difference be- tween parcels without any weed control at $125 \mathrm{~mm}$ row spacing and row hoeing at $250 \mathrm{~mm}$ row spacing was not significant at the 5\% level but was at the $10 \%$ level $(\mathrm{P}=0.07)$. The effect of the rotary hoe on weeds was poor, with $79 \%$ of the weed dry matter remaining in 19971998.

In mull soil before harvesting, the weed dry mass $\left(\mathrm{g} / \mathrm{m}^{2}\right)$ was about twice as high as in silty clay soil (Fig. 4). After inter-row hoeing, the amount of weed dry matter remaining was 55$78 \%$ of that in non-weeded parcels (row spacing $125 \mathrm{~mm}$ ). The effect of both the spring tine harrow and the rotary hoe was poor; moreover, the rotary hoe tended to increase the weed mass. 
Vol. 9 (2000): 269-278.

Only chemical control differed significantly in its effect from non-weeding.

In 1998, the spring tine harrow was adjusted to make it more aggressive and it was driven at a higher speed $(11 \mathrm{~km} / \mathrm{h}$ instead of $6 \mathrm{~km} / \mathrm{h})$. This improved the effectiveness of the method in mull soil but not in silty clay soil. The effect is not, however, seen in Fig. 4, which shows the combined data for 1997 and 1998.

The significance of row spacings for weeds becomes apparent from a comparison of nonweeded treatments in Fig 4. Doubling the row spacing from $125 \mathrm{~mm}$ to $250 \mathrm{~mm}$ increased weed dry matter by $17 \%$ in silty clay soil and by $42 \%$ in mull soil without weed control. In mull soil inter-row hoeing in rows $180 \mathrm{~mm}$ apart produced $23 \%$ fewer weeds than did hoeing in rows 250 mm apart (Fig. 4). In silty clay soil, the difference was not so big.

\section{Effects on barley yields}

The best barley yields were obtained without any weed control at $125 \mathrm{~mm}$ row spacing and with chemical control at $125 \mathrm{~mm}$ row spacing (Fig 5 ). Increasing the row spacing from the normal $125 \mathrm{~mm}$ to $250 \mathrm{~mm}$ reduced grain yields by $12-$ $13 \%$. In mull soil this decrease was statistically significant. When compared parcels without any weed control at $250 \mathrm{~mm}$ row spacing with row hoeing at $250 \mathrm{~mm}$ row spacing, inter-row hoeing did not increase the yield, and in silty clay soil it even caused a slight decrease. This could be attributed to the relatively small amount of weeds on the fields and to crop damage. Also chemical control caused no yield response, although it gave good weed control effect.

Row hoeing in 180-mm rows produced $3-7 \%$ better yields than did hoeing in 250-mm rows. The differences seemed to be bigger in mull soil than in silty clay soil, although the differences were not statistically significant.

The spring tine harrow reduced yields by $5-$ $7 \%$ and the rotary hoe by $6-10 \%$ (Fig 5). However, the differences were not statistically significant when compared with parcels without any weed control at $125 \mathrm{~mm}$ row spacing. In 1997 , the effects of these methods on yields were barely discernible but in 1998 they were clearer. This is attributed to a little more aggressive adjustments of these methods in 1998 and it explains a moderate interaction between the years in barley yields. Yields of all mechanical treatments seemed to be statistically similar in Fig 5.

\section{Discussion}

The results of weed control given here are quite similar to those reported in other studies on spring cereals with one pass per summer. In a Danish study, weed harrowing left about $40-55 \%$ and row hoeing $45 \%$ of the weed dry matter compared with no treatment (Rasmussen 1989). In a Swedish study in clay soil, the effect of weed harrowing was better, only about $25-43 \%$ of the weed dry matter remaining (Rydberg 1994). In a large inter-row hoeing study, about $20-60 \%$ of the weed dry matter remained after inter-row hoeing compared with no treatment (Johansson 1998).

Few reports exist on the results of the rotary hoe in cereals. In a study in the USA, two passes per summer were used with mechanical methods in oats. The weeding effect varied much during three experimental years. Rotary hoeing left about $63-100 \%$ and weed harrowing $47-100 \%$ of the dry matter of annual weeds compared with no treatment (Mohler and Frisch 1997). Also, chemical control was not very effective in that study.

In our study the treatments were performed only once per summer, as rainy weather prevented the second treatment in both test years. It would have been useful to repeat the mechanical treatments, especially in mull soil, because weed re-growth was rapid in wet conditions. Weed harrowing and rotary hoeing would then probably have been more successful, because they were done 1-2 weeks earlier than row hoeing. 


\section{Lötjönen, T. \& Mikkola, H. Mechanical weed control techniques}

In this study the best yields were achieved without any weed control and with herbicide spraying. Spraying did not increase the yields, although it gave good weed control. This is attributed to the relatively small amount of weeds on the experimental fields compared with the averages in Finland (Erviö and Salonen 1987). Threshold values of weed control were not achieved in most fields and so weed control did not increase the crop yields (Erviö et al. 1991). Because mechanical control methods caused some crop damage, the methods tested led to smaller yields than did the no treatment method. Generally, increasing the yield is not the only task of weed control. Keeping the weed pressure at a moderate level can be more important in the long run.

The effects of weed harrowing on grain yields were quite similar to those found in previous studies. Weed harrowing has tended to reduce yields by $0-10 \%$, but sometimes it has also had a slight increasing effect (Rasmussen 1989, Rasmussen 1992, Rydberg 1995). In the USA, weed harrowing and rotary hoeing had no effect at all on yields (Mohler and Frisch 1997).

Increasing the spacing between rows reduces grain yields. In our study, doubling the spacing from $125 \mathrm{~mm}$ to $250 \mathrm{~mm}$ reduced the yield by $12-13 \%$. In other Nordic studies, the yield decrease has been slightly less, about 4-8\% (Rasmussen 1989, Johansson 1998). It depends on weed density and hoeing success how much of the yield decrease can be compensated. Hoeing losses may be higher on farms than experimental plots, due, for instance, to trampling at the ends of fields and on slopes.

Our study showed that a row spacing of 180 $\mathrm{mm}$ is technically feasible for hoeing, but the coulters of the drill have to be modified. Yield losses were lower when compared with 250-mm rows, at least in mull soil. Furthermore, the natural competitiveness of the crop against weeds can be better utilized in narrow row spaces. The latest study in Sweden has shown that inter-row hoeing is possible in $125-\mathrm{mm}$ rows. The crop yield and the weed effect were better at spacings of $125 \mathrm{~mm}$ than $250 \mathrm{~mm}$ (Johansson 1998).

Wide row spacings may be beneficial for the control of perennial weeds. At narrow row spacings, the percentage of soil surface in the rows is relatively greater than at wide row spacings. The growth of perennial weeds can only be limited by cutting them off or pulling them up. Because the effect of inter-row hoeing is poor in rows (only covering the weeds) it is possible that perennials "hide themselves" in the rows. Effectiveness against perennials may therefore be poorer at narrow row spacings. The effect of inter-row hoeing on perennial weeds has, however, been studied very little to date; more studies need to be conducted on this subject in the future.

In conclusion, the advantage of inter-row hoeing is its effectiveness against weeds. Because increasing the row spacing has a yield-cost, it may be, that hoeing is really beneficial only in situations of high weed infestation. The decrease in crop yield can be kept at a moderate level by increasing the row spacing to no more than $180 \mathrm{~mm}$ instead of $250 \mathrm{~mm}$ for hoeing. More attention should be paid to weed control within crop rows. This and previous studies has shown that the advantage of the spring tine harrow and rotary hoe is usually the small yield loss. The disadvantage is the poor effect on big weeds. More than one treatment per summer is often needed with all the mechanical methods tested.

Mechanical weeding methods are useful in organic farming but are seldom economically profitable in conventional farming due to the low price and high efficiency of cereal herbicides (Lötjönen and Mikkola 1997). In organic farming it may be wiser to strive for low weed rates than maximum yields. 


\section{AGRICULTURAL AND FOOD SCIENCE IN FINLAND}

Vol. 9 (2000): 269-278.

\section{References}

Erviö, L.-R. \& Salonen, J. 1987. Changes in the weed population of spring cereals in Finland. Annales Agriculturae Fenniae 26: 201-226.

- , Tanskanen, T. \& Salonen, J. 1991. Profitability of chemical weed control in spring cereals. Annales Agriculturae Fenniae 30: 199-206.

Finnish Meteorological Institute 1999. Weather data obtained from the Finnish Meteorological Institute.

Johansson, D. 1998. Radhackning med och utan efterredskap i stråsäd. Slutrapport för fältförsök 1995-1997. Institutionen för markvetenskap. Rapporter från jordbearbetningsavdelningen nr. 94. Uppsala: Sveriges lantbruksuniversitet. $49 \mathrm{p}$.

Lötjönen, T. \& Mikkola, H. 1997. Rikkakasvien torjunta viljoista riviväliharauksella. Maatalouden tutkimuskeskus. Vakolan tiedote 74/97. Vihti: Maatalousteknologian tutkimuslaitos. 22 p.

Mattsson, B. \& Sandström, M. 1994. Icke-kemisk bekämpning i stråsäd och oljeväxter. Aktuellt från lantbruksuniversitetet 423. Uppsala: Sveriges lantbruksuniversitet. $23 \mathrm{p}$.

Mohler, C.L. \& Frisch, J.C. 1997. Mechanical weed control in oats with a rotary hoe and tine weeder. Proceedings of the annual meeting of the Northeastern Weed Science Society, Newport, Rhode Island, 69.1.1997. 51: 2-6.

Pullen, D.W.M. \& Cowell, P.A. 1997. An evaluation of the performance of mechanical weeding mechanisms for use in high speed inter-row weeding of arable crops. Jour- nal of Agricultural Engineering Research 67: 27-34. Rasmussen, J. 1989. Forsøg med ukrudtsharvning och radrensning i korn. Nordic Plant Protection Conference 1989: Section of Botany, Zoology, Nematology, Virology, Weed and Chemistry. Helsingør (Denmark). p. 345-354.

- 1992. Testing harrows for mechanical control of annual weeds in agricultural crops. Weed Research 32: 267-274.

- \& Ascard, J. 1995. Weed control in organic farming systems. In: Glen, D.M. et al. (eds.). Ecology and integrated farming systems. Bristol: IACR-Long Ashton Research Station. p. 49-67.

- \& Svenningsen T. 1995. Selective weed harrowing in cereals. Biological Agriculture and Horticulture 12: 29-46.

Rydberg, N.T. 1994. Weed harrowing - the influence of driving speed and driving direction on degree of soil covering and the growth of weed and crop plants. Biological Agriculture and Horticulture 10: 197-205.

- 1995. Weed harrowing in growing cereals. Significance of time of treatment, driving speed, harrowing direction and harrowing depth. Dissertation. Institutionen för växtodlingslärä. Uppsala: Sveriges lantbruksuniversitet. 19 p. + 4 appendix.

SAS Institute Inc. 1988. SAS/STAT ${ }^{\circledR}$ User's guide, Release 6.03 edition. Cary, NC: SAS Institute Inc. $1028 \mathrm{p}$. 
Lötjönen, T. \& Mikkola, H. Mechanical weed control techniques

\title{
SELOSTUS
}

\section{Kolme viljojen mekaanista rikkakasvintorjuntamenetelmää}

\author{
Timo Lötjönen ja Hannu Mikkola \\ Maatalouden tutkimuskeskus
}

Luonnonmukaisessa viljan viljelyssä rikkakasvit torjutaan usein rikkakasviäestyksellä. Äestyksen teho on heikko suuriin siemenrikkakasveihin ja kestorikkakasveihin. Siksi tässä tutkimuksessa kehitettiin äestystä järeämpi torjuntamenetelmä eli viljoille sopiva riviväliharaus. Kaksivuotisessa kenttäkokeessa harausta verrattiin rikkakasviäestykseen, tähtipyörä-äestykseen ja kemialliseen torjuntaan. Kokeet tehtiin kahdella eri maalajilla, koekasvina oli ohra ja torjuntakäsittelyt tehtiin vain kerran kasvukaudessa.

Torjuntamenetelmien tehoa verrattiin punnitsemalla jäljellä olevat rikkakasvit juuri ennen puintia. Riviväliharaus oli mekaanisista torjuntamenetelmistä tehokkain. Rikkakasviäkeen teho oli haraukseen verrattuna yhtä hyvä hiesusavella, mutta huonompi kostealla multamaalla. Tähtipyörä-äkeen teho osoittautui heikoimmaksi. Mekaanisen torjunnan tehoa olisi ilmeisesti voitu parantaa toistamalla käsittelyt myöhemmin kasvukaudella. Herbisidiruiskutus oli kummallakin maalajilla mekaanista torjuntaa tehokkaampi menetelmä.

Harauksen edellyttämä rivivälin leventäminen $125 \mathrm{~mm}$ :stä $250 \mathrm{~mm}$ :iin pienensi ohran satoa 12 13\%. Käytettäessä $180 \mathrm{~mm}: n$ riviväliä satotappio oli pienempi. Haraus ei lisännyt satoa, koska rikkakasveja oli suhteellisen vähän. Rikkakasvi- ja tähtipyörä-äestys pienensivät satoa 5-10\%. Vaikka harauksen torjuntateho onkin melko hyvä, se ei lyhyellä tähtäimellä näyttäisi korvaavan rivivälin leventämisestä koituvaa sadonmenetystä. Luomuviljelyssä rikkakasvien kunnollinen torjunta voi pidemmällä aikavälillä olla kuitenkin maksimaalista satoa tärkeämpi tavoite. 